\title{
Pelibatan Manajemen dan Stakeholder Sekolah dalam Penguatan Pendidikan Karakter di Era Global ${ }^{1}$
}

\author{
Oleh \\ Dr. Hadiyanto, M.Ed. ${ }^{2}$
}

\section{A. Latar Belakang}

Dalam Undang-Undang No 20 Tahun 2003 tentang Sistem Pendidikan Nasional pasal 3 disebutkan bahwa pendidikan nasional berfungsi mengembangkan kemampuan dan membentuk watak serta peradaban bangsa yang bermartabat dalam rangka mencerdaskan kehidupan bangsa, bertujuan untuk berkembangnya potensi peserta didik agar menjadi manusia yang beriman dan bertakwa kepada Tuhan Yang Maha Esa, berakhlak mulia, sehat, berilmu, cakap, kreatif, mandiri, dan menjadi warga negara yang demokratis serta bertanggung jawab.

Untuk mencapai tujuan pendidikan nasional tersebut, berbagai upaya dilaksanakan pemerintah Indonesia untuk membuat agar penyelenggaraan pendidikan menjadi lebih baik, misalnya dengan program revolusi mental oleh Presiden Jokowi dan dengan memperbaharui dan melengkapi peraturan perundangan pendidikan, seperti Peraturan Presiden Republik Indonesia Nomor 87 Tahun 2017 tentang Penguatan Pendidikan Karakter.

Upaya yang lebih operasional untuk meningkatkan pendidikan karakter dilaksanakan di tingkat sekolah dengan berbagai program yang dibuat oleh Kemdikbud misalnya dengan program Penguatan Pendidikan Karakter (PPK), dan implementasi dari Permendiknas No. 39 Tahun 2008 tentang Pembinaan Kesiswaan.

Namun di balik upaya-upaya yang telah dilaksanakan, masih dijumpai kendalakendala di bidang pendidikan yang dapat mencoreng nama baik upaya peningkatan mutu pendidikan, seperti tawuran, menyontek dan plagiarism, penyalahgunaan wewenang dalam pengelolaan dana (korupsi), 80\% kantin kejujuran di sekolah gulung tikar karena merugi, penggunaan Narkoba, siswa gantung diri, bunuh diri karena tidak mampu membayar uang sekolah atau tidak lulus ujian, dan bahkan tindakan asusila atau perilaku menyimpang lainnya. Kendala-kendala itu dijumpai mulai dari tingkat SD, SMP, SMA, SMK dan bahkan juga dilakukan oleh para mahasiswa dan civitas akademika di lingkungan perguruan tinggi, atau pun para petinggi Negara lainnya.

Dalam skala yang lebih luas di era globalisasi, permasalahan-permasalahan yang terkait dengan pendidikan karakter menjadi lebih banyak tantangannya dengan kehadiran teknologi informasi yang lebih canggih dan digital yang berada di genggaman setiap individu untuk mengakses berbagai bentuk informasi dan koneksi

\footnotetext{
1 Disampaikan pada Seminar Nasional Penguatan Kepemimpinan, Manajemen, Literasi Teknologi Informasi, dan Pendidikan Karakter di Era Global

2 Lektor Kepala pada Fakultas Ilmu Pendidikan, Universitas Negeri Padang
} 
yang apabila salah dalam penggunaannya dapat lebih merusak karakter bangsa seperti pornografi, kebencian, terorisme, dan hoax dibandingkan dengan yang telah disebutkan di atas.
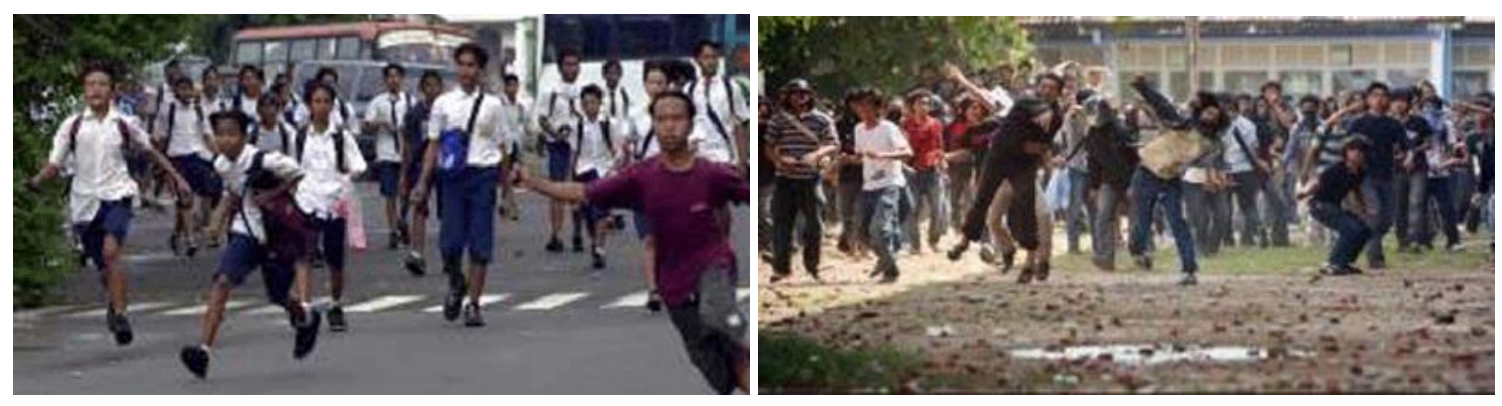

Tawuran di kalangan pelajar di Indonesia

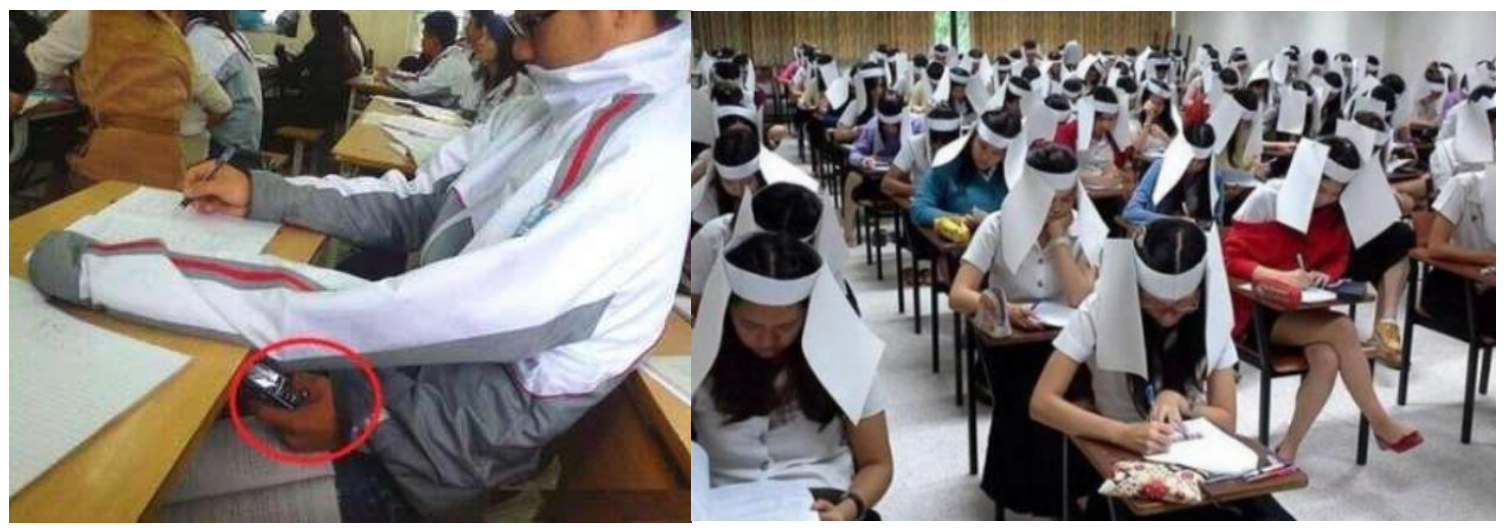

Nyontek melalui HP dan Pencegahan Menyontek Masal

Kekhawatiran ini sebenarnya juga telah dikemukakan oleh Vessel dan Huitt (2005) sebagai berikut:

Moral character development has been a topic of concern for thousands of years. It was central to the development of American schooling, but lost favor in the middle of the 20th century. Over the last several decades there has been increased attention paid to the importance of moral character as central to the purpose of schooling.

Pendidikan karakter merupakan proses yang sangat penting bagi peserta didik untuk menjadi manusia yang seutuhnya. Pendidikan karakter dilaksanakan dengan menyentuh lebih banyak ranah afektif dibandingkan ranah kognitif maupun psikomotorik. Proses pendidikan pada ranah ini sangat penting karena telah diyakini bahwa keberhasilan kelak seseorang dalam kehidupannya bukan didominasi oleh ranah kognitif, justru oleh ranah-ranah yang lain.

Dengan memperhatikan peristiwa-peristiwa yang sangat memprihatinkan dan menghawatirkan semua pihak, perlu diupayakan langkah-langkah yang lebih konkrit untuk meningkatkan proses pendidikan kepada peserta didik melalui pendidikan karakter untuk mengubah tingkah laku peserta didik agar sesuai dengan cita-cita 
pendidikan nasional seperti yang disebutkan dalam Undang-Undang Sistem Pendidikan Nasional tersebut di atas. Pendidikan karakter menjadi tanggung jawab bersama antara orang tua, pendidik, manajer sekolah, stakerholder dan bahkan masyarakat luas.

\section{B. Pengertian Karakter dan Pendidikan Karakter}

Dalam pandangan Tadkiroatun Musfiroh (Dit PSMP, 2011), karakter mengacu kepada serangkaian sikap (attitudes), perilaku (behaviors), motivasi (motivations), dan keterampilan (skills).

Chaplin's Dictionary of Psychology (dalam Dean Borgman) mendefinikan 'character' sebagai

A consistent and enduring property or quality by means of which a person, object, or event can be identified; the integration or synthesis of individual traits into a unity; the individual's personality considered from an ethical or moral point of view.

Dalam agama Islam, istilah yang digunakan untuk menunjuk 'karakter' adalah 'akhlak'. Akhlak merupakan salah satu dari ajaran Islam yang memiliki kedudukan yang sangat penting. Nabi Muhammad saw. mengisyaratkan bahwa kehadirannya di bumi ini adalah untuk menyempurnakan akhlak manusia. Nabi Muhammad saw. bersabda:

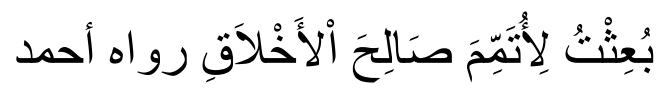

Artinya: "Aku hanya diutus untuk menyempurnakan akhlak yang mulia". (HR. Ahmad).

Keharusan menjunjung tinggi akhlakul karimah lebih dipertegas dengan pernyataan yang menghubungkan akhlak dengan kualitas kemauan, bobot amal. Sabda Nabi Muhammad saw. yang diriwayatkan oleh Abdullah Tirmidzi menyebutkan:

$$
\text { خِيَارُكُمْ أَحَاسِنْكُمْ أَخْلَفًَا رو اه التر مذي }
$$

Artinya: "Sebaik-baik kamu adalah yang paling baik akhlaknya (HR. al-Tirmidzi).

Hadits di atas menunjukkan bahwa akhlak Islam tidak lepas dari realitas hidup. Akhlak merupakan sistem perilaku yang diwajibkan dalam agama Islam melalui nash al-Quran dan Hadis.

Selain dengan dasar di atas, Allah menuntun manusia agar menjadikan Nabi Muhammad saw. sebagai teladan yang terbaik yang harus dicontoh sikap dan perilakunya, seperti firman Allah swt.:

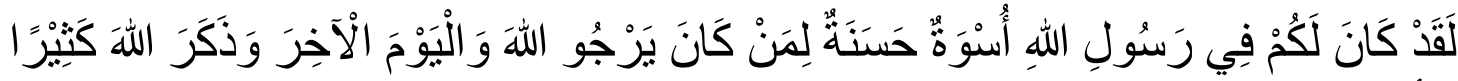

Artinya: "Sesungguhnya telah ada pada (diri) Rasulullah itu suri teladan yang baik bagimu (yaitu) bagi orang yang mengharap (rahmat) Allah dan (kedatangan) hari kiamat dan dia banyak menyebut Allah.” (QS. al-Ahzab : 21). 
Telah banyak sekali contoh-contoh perilaku Nabi Muhammad yang harus ditiru oleh manusia di dunia. Allah memilih Nabi Muhammad saw. sebagai teladan terbaik karena keluhuran budi atau akhlaknya. Semua yang perintah Allah dalam al-Quran selalu dilaksanakan dan yang dilarang Allah dalam al-Quran pasti dijauhi Nabi Muhammad saw. Adapun akhlak yang dimiliki oleh Nabi Muhammad saw. Yang sangat populer dihapahmi dalam ajaran Islam ada empat, yaitu sidiq yang berarti jujur, amanah yang berarti dapat dipercaya dalam kata dan perbuatannya, tabligh yang berarti menyampaikan apa saja yang diterimanya dari Allah (wahyu) kepada umat manusia, dan fathonah yang berarti cerdas atau pandai, sehingga dapat mengatasi semua permasalahan yang dihadapinya.

Dalam rangka pembentukan karakter peserta didik, orang tua, sekolah dan masyarakat memegang peranan yang sangat penting. Pengertian pendidikan karakter menurut para ahli diantaranya menurut Vessels, G., \& Huitt, W. (2005) adalah:

Character education is a national movement creating schools that foster ethical, responsible, and caring young people by modeling and teaching good character through emphasis on universal values that we all share. It is the intentional, proactive effort by schools, districts, and states to instill in their students important core, ethical values such as caring, honesty, fairness, responsibility, and respect for self and others.

Lebih lanjut dijelaskan bahwa pendidikan karakter adalah segala sesuatu yang dilakukan guru, yang mampu mempengaruhi karakter peserta didik. Guru membantu membentuk watak peserta didik. Hal ini mencakup keteladanan bagaimana perilaku guru, cara guru berbicara atau menyampaikan materi, bagaimana guru bertoleransi, dan berbagai hal terkait lainnya.

Namun karena prinsip-prinsip religious ini ditinggalkan, maka Shehu (2011) menyebutkan bahwa beberapa orang karena cinta mereka terhadap dunia materi, telah menjadi sangat egois hanya memikirkan diri mereka dan barang-barang milik mereka. Dengan demikian, prinsip moral cinta, perhatian, belas kasihan, kerendahan hati, kebebasan, toleransi, dan saling menghormati telah bergeser menjadi kebencian, pelecehan, kesengsaraan, kebanggaan, ketidakadilan, intoleransi dan pertumpahan darah. Penyakit sosial yang telah menimpa desa global kita telah muncul sebagai akibat dari kegagalan untuk mengerti prinsip dasar moralitas dengan kaitannya dengan etika sehari-hari.

Dengan dasar pengertian-pengertian di atas, maka dapat dipahami bahwa pendidikan karakter di sekolah adalah suatu sistem penanaman nilai-nilai karakter kepada warga sekolah yang meliputi komponen pengetahuan, kesadaran atau kemauan, dan tindakan untuk melaksanakan nilai-nilai tersebut, baik terhadap Tuhan Yang Maha Esa (YME), diri sendiri, sesama, lingkungan, maupun kebangsaan sehingga menjadi manusia insan kamil. Dalam pendidikan karakter di sekolah, semua komponen pendidikan di sekolah harus diintegrasikan, yaitu isi kurikulum, proses pembelajaran dan penilaian, pengelolaan sekolah, pelaksanaan aktivitas atau kegiatan ko-kurikuler, sarana prasarana, pembiayaan, dan ethos kerja seluruh warga dan lingkungan sekolah. 


\section{Sumber-Sumber Karakter di Sekolah}

Seperti yang telah dipahami bahwa karakter adalah nilai-nilai yang diyakini oleh individu dan menjadi panutan dalam bertingkah laku. Oleh karena itu, nilai-nilai karakter tersebut dapat berasal dari ajaran agama yang dianut, norma dan tatanan yang dianut masyarakat, adat istiadat, maupun ilmu pengetahuan.

Dalam rangka pendidikan karakter di sekolah, sebenarnya Standar Kompetensi Lulusan merupakan salah satu sumber karakter yang dapat digunakan sebagai sumber untuk melakukan pendidikan karakter melalui berbagai mata pelajaran dan proses pendidikan di sekolah. Sebagai contoh, Direktorat Pembinaan SMP (2011) melakukan penelaahan nilai-nilai yang terdapat pada 21 butir SKL untuk SMP. Dari ke-21 butir SKL tersebut didapatkan nilai-nilai karakter yang dikelompokkan ke dalam lima kategori nilai utama, yaitu nilai-nilai perilaku manusia dalam hubungannya dengan Tuhan Yang Maha Esa, diri sendiri, sesama manusia, dan lingkungan serta kebangsaan. Berikut adalah daftar nilai-nilai utama yang dimaksud dan diskripsi ringkasnya.

1. Nilai karakter dalam hubungannya dengan Tuhan

Nilai karakter dalam kelompok ini adalah religious, yaitu suatu keadaan pada diri seseorang di mana pikiran, perkataan, dan perilaku atau tindakan seseorang selalu berdasarkan pada nilai-nilai ketuhanan dan/atau ajaran agama.

2. Nilai karakter dalam hubungannya dengan diri sendiri

Diantara nilai karakter dalam kelompok ini adalah jujur, bertanggung jawab, bergaya hidup sehat, disiplin, kerja keras, percaya diri, berjiwa wira usaha, berpikir logis, kritis, kreatif, dan inovatif, mandiri, ingin tahu, dan cinta ilmu.

3. Nilai karakter dalam hubungannya dengan sesama

Nilai karakter yang termasuk dalam kelompok ini diantaranya sadar akan hak dan kewajiban diri dan orang lain, patuh pada aturan-aturan social, menghargai karya dan prestasi orang lain, santun, dan demokratis.

4. Nilai karakter dalam hubungannya dengan lingkungan

Peduli sosial dan lingkungan adalah sikap dan tindakan yang selalu berupaya mencegah kerusakan pada lingkungan alam di sekitarnya, dan mengembangkan upaya-upaya untuk memperbaiki kerusakan alam yang sudah terjadi dan selalu ingin memberi bantuan bagi orang lain dan masyarakat yang membutuhkan.

5. Nilai kebangsaan

Cara berpikir, bertindak, dan wawasan yang menempatkan kepentingan bangsa dan negara di atas kepentingan diri dan kelompoknya. Diantara nilai karakter yang ada di kelompok ini adalah nasionalis dan menghargai keberagaman.

Pengelompokan nilai-nilai karakter di atas hanya merupakan sampel dari yang dilakukan oleh Direktorat Pembinaan SMP (2011). Sementara itu, para ahli atau lembaga-lembaga lain dapat membuat pengelompokan yang berbeda, dan dimungkinkan sesuai dengan penekanan mereka, seperti yang dilakukan oleh Pusat 
Kurikulum Kementerian Pendidikan Nasional (2010) serta oleh Direktorat Jenderal Pendidikan Tinggi Kementerian Pendidikan Nasional (2010).

\section{Strategi Implementasi Pendidikan Karakter}

Untuk membuat agar para peserta didik mempunyai karakter seperti yang diharapkan oleh sekolah, ada berbagai strategi yang dapat dilaksanakan oleh sekolah. Tugas sekolah adalah memfasilitasi agar peserta didik maupun guru dan tenaga kependidikan lainnya dapat berperilaku yang berkarakter. Sebagai contoh, Lickona, Schaps and Lewis (2000) seperti yang dikutip oleh Vessel dan Huitt (2005) menyebutkan ada 11 prinsip pendidikan karakter yang efektif, yang merupakan caracara untuk membuat karakter benar-benar menjadi bagian dari tingkah laku peserta didik, yaitu:

1. Promote core ethical values as the basis of good character.

2. Define character comprehensively to include thinking, feeling, and behavior.

3. Promote core values intentionally and proactively through all parts of school life.

4. Are caring communities.

5. Give students opportunities for moral action.

6. Have meaningful and challenging academic curriculums that respect learners.

7. Develop students' intrinsic motivation.

8. Have professionals who exemplify core values and maintain a moral community.

9. Require moral leadership from educators and students.

10. Recruit parents and community members as full partners.

11. Evaluate school character, student character, and adults as character educators.

Grand design Kementerian Pendidikan dan Kebudayaan menyebutkan bahwa pendidikan karakter dalam konteks totalitas proses psikologis dan sosial-kultural dikelompokan dalam: Olah Hati (Spiritual and emotional development), Olah Pikir (intellectual development), Olah Raga dan Kinestetik (Physical and kinestetic development), dan Olah Rasa dan Karsa (Affective and Creativity development). (Kemdiknas, 2010).

Pendidikan karakter dapat dilihat pada dua latar/domain, yaitu pada latar makro dan latar mikro. Latar makro bersifat nasional yang mencakup keseluruhan mulai dari perencanaan sampai dengan ilmpementasi pengembangan nilai/karakter yang melibatkan seluruh pemangku kepentingan pendidikan nasional. Pada latar makro program pengembangan nilai/karakter dapat digambarkan sebagai berikut. 


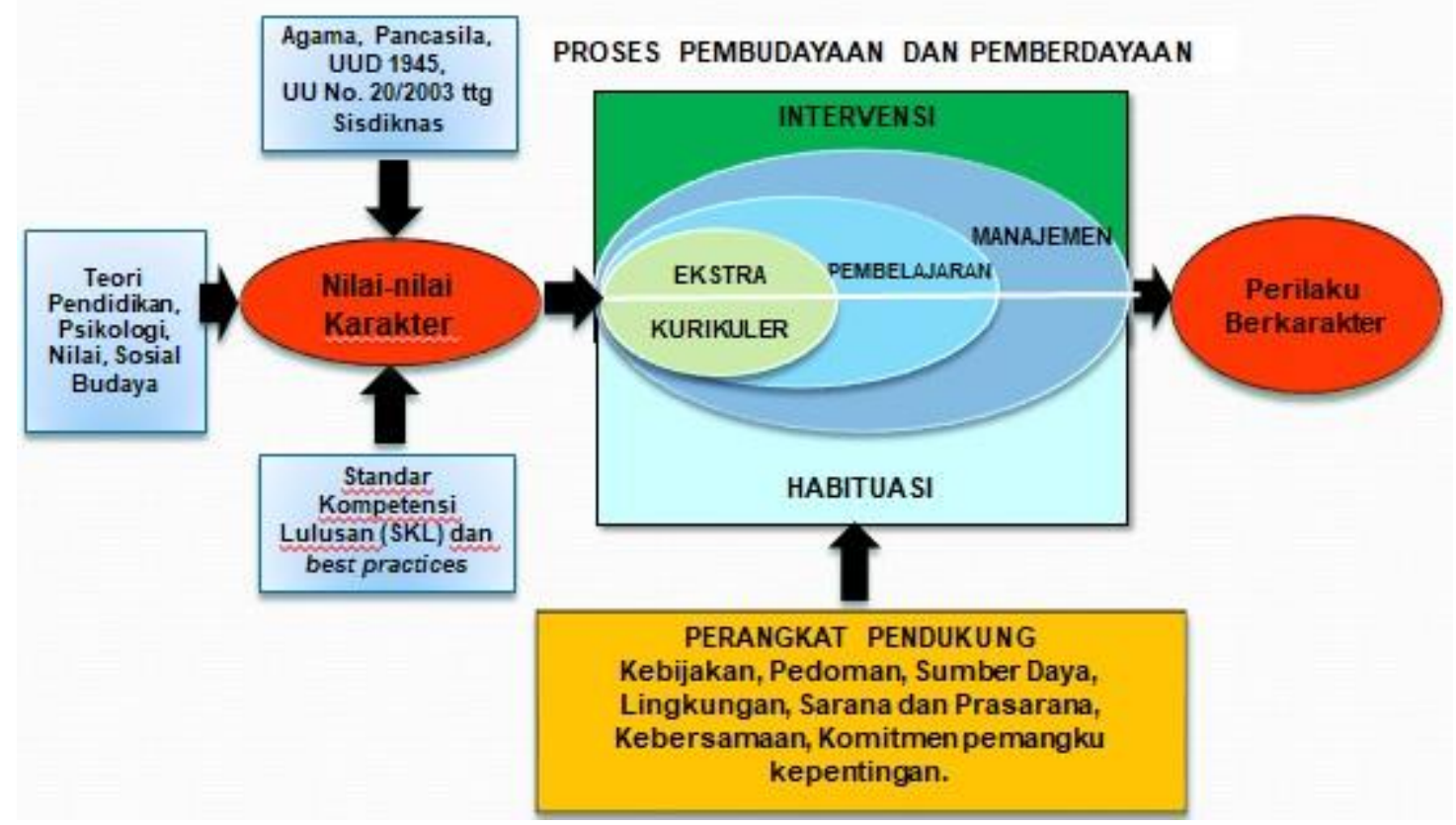

Gambar 1. Konteks Makro Pengembangan Karakter (Kemdiknas, 2010)

Pada konteks mikro pengembangan karakter berlangsung dalam suatu satuan pendidikan atau sekolah secara holistik. Sekolah merupakan leading sector, berupaya memanfaatkan dan memberdayakan semua lingkungan belajar yang ada untuk memulai, memperbaiki, menguatkan, dan menyempurnakan secara terus menerus proses pendidikan karakter di sekolah. Program pengembangan karakter pada latar mikro dapat digambarkan sebagai berikut.

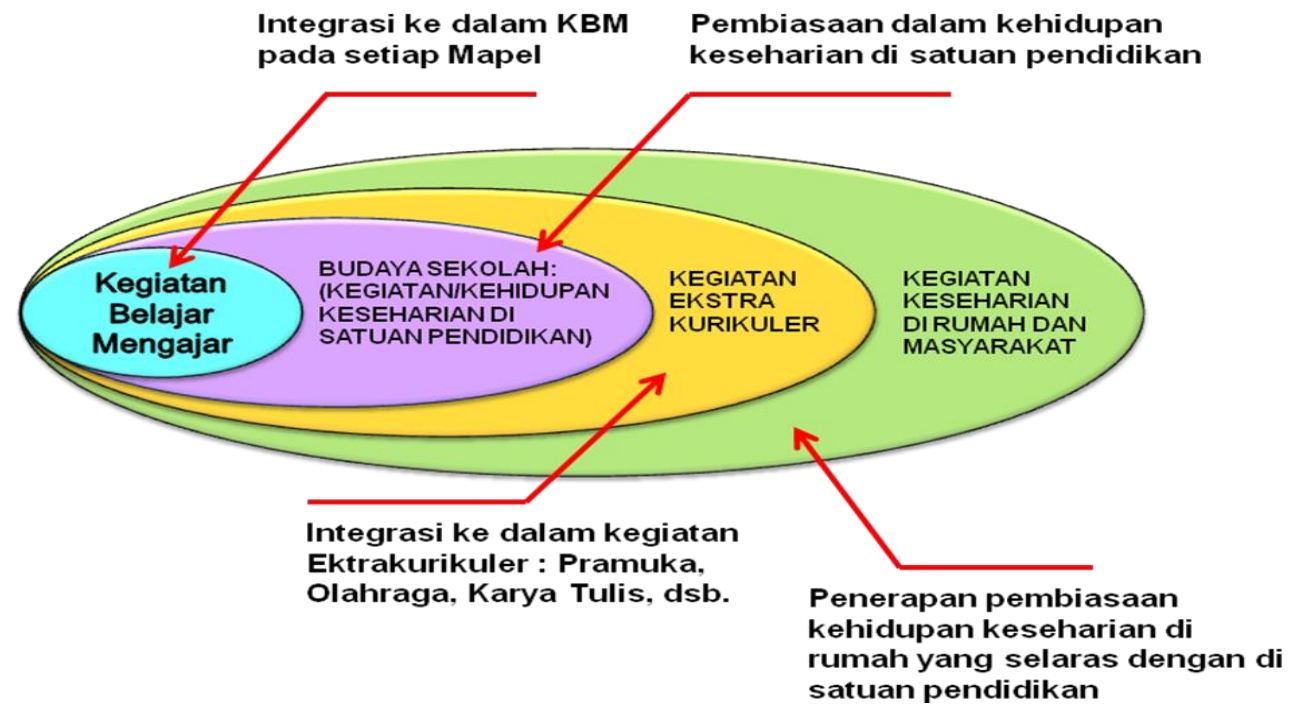

Gambar 2. Konteks Mikro Pengembangan Nilai/Karakter (Kemdiknas, 2010) 
Dari dua gambar di atas dapat dipahami bahwa pengembangan dan/atau pendidikan karakter kepada peserta didik di sekolah dapat dilaksanakan melalui dua pendekatan, yaitu makro dan mikro. Baik dalam skala makro maupun mikro sekolah memegang peranan yang sangat penting agar pendidikan karakter benar-benar terinternalisasi kepada peserta didik. Oleh karena itu, peranan guru dalam proses pembelajaran di kelas maupun kegiatan ekstra kurikuler di luar kelas serta peran kepala sekolah menjadi sangat penting.

Hampir sama dengan pendapat di atas, Pusat Kurikulum Balitbang Kemdiknas (2010) juga mengembangkan pendidikan karakter dengan istilah 'Pengembangan Pendidikan Budaya dan Karakter Bangsa'. Pendidikan karakter dapat dilaksanakan melalui proses: 1) pengembangan diri, 2) pengintegrasian dalam mata pelajaran, serta 3) budaya sekolah. Proses pengembangan diri dilaksanakan dengan: a) kegiatan rutin sekolah, b) kegiatan spontan, c) keteladanan, dan d) pengkondisian.

Sebagai bentuk realisasi dari konsep-konsep pendidikan karakter yang telah disebutkan di atas, Direktorat Pembinaan SMP Ditjen Pendidikan Dasar Kementerian Pendidikan dan Kebudayaan mengembangkan Panduan Pendidikan Karakter di Sekolah Menengah Pertama. Panduan ini dilaksanakan dalam konteks mikro di sekolah. Menurut Direktorat Pembinaan SMP (2011), pendidikan karakter dapat dilaksanakan melalui tiga strategi, yaitu 1) melalui proses pembelajaran di kelas, 2) melalui kegiatan ekstra kurikuler, dan 3) melalui manajemen sekolah.

\section{E. Pelibatan Manajemen dan Stakeholder dalam Pendidikan Karakter}

Mengintegrasikan pendidikan karakter ke dalam manajemen sekolah berarti melaksanakan proses manajemen sekolah dijiwai oleh karakter-karakter terpuji yang sengaja ditanamkan kepada peserta didik maupun warga sekolah lainnya. Untuk itu, kepala sekolah harus mendisain pendidikan karakter melalui berbagai aspek manajemen sekolah seperti kurikulum dan pembelajaran, peserta didik, sarana dan prasarana, pendidik dan tenaga kependidikan, pembiayaan, dan hubungan antara sekolah dengan masyarakat. Di samping itu, karena manajemen sekolah merupakan suatu proses, maka kepala sekolah juga harus menanamkan nilai-nilai karakter pada proses manajemen seperti perencanaan, pelaksanaan, pengawasan dan evaluasi. Karena manajemen sekolah yang dikembangkan di Indonesia adalah manajemen berbasis sekolah (school-based management), maka prinsip-prinsip manajemen yang diamanatkan pasal 49 ayat (1) Peraturan Pemerintah Nomor 19 Tahun 2005 tentang Standar Nasional Pendidikan berupa kemandirian, kemitraan, partisipasi, keterbukaan dan akuntabilitas harus dapat diwujudkan.

Perpres Nomor 87 Tahun 2017 pasal 6 ayat (3) menyebutkan bahwa Penguatan Pendidikan Karakter (PPK) pada satuan pendidikan jalur pendidikan formal dilaksanakan dengan prinsip manajemen berbasis sekolah/madrasah. Sedangkan pada ayat (4) disebutkan bahwa penyelenggaraan PPK tersebut merupakan tanggung jawab kepala satuan Pendidikan Formal dan guru.

Pasal 12 Perpres Nomor 87 Tahun 2017 menyebutkan bahwa PPK dilaksanakan oleh kementerian / lembaga sebagai berikut: 
1. Kementerian yang menyelenggarakan urusan pemerintahan di bidang pendidikan dan kebudayaan;

2. Kementerian yang menyelenggarakan urusan pemerintahan di bidang agama;

3. Kementerian yang menyelenggarakan urusan pemerintahan dalam negeri; dan

4. Pemerintah Daerah.

Selain kepala sekolah sebagai manajer pendidikan, Mulyasa (2013) menyebutkan peran dan fungsi komite sekolah dalam pendidikan karakter, yaitu sebagai pemberi pertimbangan (advisory), pendukung (supporting), pengontrol (controlling agency) dan mediator antara pemerintah (ekskutif), dengan masyarakat, dan sekolah dalam implementasi pendidikan karakter.

Bagian berikut menguraikan secara singkat pelaksanaan pengelolaan masing-masing komponen dalam system persekolahan dalam mendukung internalisasi nilai-nilai karakter kepada seluruh pihak di sekolah.

1. Manajemen Kurikulum dan Pembelajaran Berbasis Pendidikan Karakter

Seperti yang telah disebutkan di atas bahwa sumber nilai karakter yang menjadi referensi pendidikan karakter di sekolah kurikulum dan diinternalisasikan melalui proses pembelajaran. Lickona (2012) menyarankan nilai-nilai moral (karakter) yang sebaiknya diajarkan di sekolah meliputi: sikap hormat, bertanggung jawab, kejujuran, keadilan, toleransi, bijaksana, disiplin diri, tolong menolong, peduli sesame, keberanian, dan sikap demokratis.

Dalam proses pembelajaran di kelas, guru dapat secara jeli menanamkan nilai-nilai karakter sesuai dengan topik atau pokok bahasan dan/atau seperti yang telah dituangkan dalam silabus dan RPP pada masing-masing mata pelajaran. Di samping itu, dalam proses pembelajaran di kelas, guru pun menjadi peran kunci sebagai pembina karakter peserta didik melalui keteladanan tingkah laku mereka dalam pembelajaran di kelas. Setiap topik dalam suatu mata pelajaran, para guru dapat menanamkan nilai-nilai karakter yang paling relevan. Dengan demikian, tidak ada suatu mata pelajaran yang bebas dari penanaman nilai-nilai karakter kepada peserta didik.

Untuk membantu memfasilitasi para guru mengembangkan pendidikan karakter yang terintegrasi dengan silabus dan RPP, Direktorat Pembinaan SMP (2011) telah menyusun contoh silabus dan RPP berbasis pendidikan karakter yang dapat diadaptasi oleh para guru dalam setiap mata pelajaran. Di samping itu, para penulis seperti Nurul Zuriah (2008) juga telah mengembangkan contoh penerapan nilai-nilai karakter dalam proses pembelajaran yang dapat digunakan sebagai inspirasi untuk menciptakan pembelajaran berbasis karakter di kelas.

Tugas kepala sekolah dalam hal ini adalah meyakinkan bahwa masing-masing guru telah melaksanakan pendidikan karakter kepada peserta didiknya, mulai dari perencanaan pembelajaran (membuat silabus dan RPP), melaksanakan proses pembelajaran di kelas dan melaksanakan evaluasi pembelajaran berbasis pendidikan karakter dengan optimal. 
2. Manajemen Pendidik dan Tenaga Kependidikan Berbasis Pendidikan Karakter

Dalam melaksanakan manajemen pendidik dan tenaga kependidikan kepala sekolah dapat melakukan pembinaan yang berkarakter, dimulai dari merencanakan kegiatan, mengarahkan, memimpin, mengawasi, mengevaluasi serta mensupervisi pendidik dan tenaga kependidikan. Kepala sekolah harus dapat menunjukkan keteladanan dalam banyak hal seperti memimpin rapat, berkomunikasi dan bertutur kata, kedisiplinan. Kata-kata bijak Ki Hajar Dewantara: Ing Ngarso sung Tulodho, Ing Madyo Mangun Karso, Tut Wuri Handayani, harus dapat diwujudkan oleh kepala sekolah. Pembinaan kepada pendidik dan tenaga kependidikan dengan berbagai aturan yang ada tidak akan berhasil dengan optimal manakala kepala sekolah tidak mampu memberikan contoh yang baik bagi para pendidik dan tenaga kependidikan lainnya di sekolah.

3. Manajemen Peserta Didik Berbasis Pendidikan Karakter

Pembinaan peserta didik diatur dalam Permendiknas Nomor 39 Tahun 2008 tentang pembinaan kesiswaan. Kepala sekolah diharapkan mampu menciptakan programprogram atau kegiatan yang dapat mengantarkan peserta didik memiliki bakat, minat, kompetensi dan mampu bersaing atau berprestasi di bidang akademik maupun non akademik secara maksimal. Tidak kalah pentingnya, program dan kegiatan yang ada juga dapat meningkatkan karakter peserta didik.

Dalam rangka mencapai tujuan di atas, kepala sekolah perlu merealisasikan program dan kegiatan sekolah dengan materi sesuai dengan Permendiknas Nomor 39 Tahun 2008, yaitu: 1) Keimanan dan ketaqwaan terhadap Tuhan Yang Maha Esa; 2) Budi pekerti luhur atau akhlak mulia; 3) Kepribadian unggul, wawasan kebangsaan, dan bela negara; 4) Prestasi akademik, seni, dan/atau olahraga sesuai bakat dan minat; 5) Demokrasi, hak asasi manusia, pendidikan politik, lingkungan hidup, kepekaan dan toleransi sosial dalam konteks masyarakat plural; 6) Kreativitas, keterampilan, dan kewirausahaan; 7) Kualitas jasmani, kesehatan, dan gizi berbasis sumber gizi yang terdiversifikasi ; 8) Sastra dan budaya; 9) Teknologi informasi dan komunikasi; 10) Komunikasi dalam bahasa Inggris;

Pembinaan nilai-nilai karakter peserta didik harus diintegrasikan ke dalam berbagai program atau kegiatan kesiswaan seperti pembiasaan beribadah setiap hari, peringatan hari-hari besar nasional, hari besar keagamaan, latihan kepemimpinan, Pramuka, Palang Merah Remaja, UKS, dan kegiatan lainnya yang dapat menyentuh karakter peserta didik.

4. Manajemen Sarana dan Prasarana Pendidikan Berbasis Pendidikan Karakter

Apabila nilai-nilai karakter telah diintegrasikan ke dalam kurikulum, program dan kegiatan, maka pelaksanaannya tidak dapat dipisahkan dengan kebutuhan dan ketersediaan sarana dan prasarana pendidikan di sekolah. Sekolah harus dapat menyediakan sarana dan prasarana pendidikan sehingga pembentukan nilai-nilai karakter pada perilaku keseharian peserta didik di sekolah menjadi lebih nyata.

Untuk mengajarkan nilai-nilai ketuhanan agar peserta didik terbiasa dan rajin beribadah, maka sekolah harus menyediakan tempat ibadah agar mereka tidak terkendala saat akan melaksanakan kegiatan tersebut. Dalam mengajarkan nilai-nilai 
kebersihan, sekolah tidak hanya memasang slogan 'kebersihan adalah sebagian daripada iman' atau 'bersih itu indah dan sehat', sekolah harus menyediakan alat-alat kebersihan seperti tempat sampah, tempat cuci tangan dengan air bersih agar peserta didik tidak sembarangan membuang sampah serta setiap saat dapat mencuci tangan dengan mudah.

Di era globalisasi sekarang ini, kepala sekolah harus senantiasa waspada terhadap penggunaan peralatan teknologi informasi yang digunakan peserta didik dalam proses pembelajaran atau mengakses informasi lainnya, jangan sampai mereka terjebak pada perilaku yang tidak terkendali sehingga malah mengakses situs-situs yang bersifat tidak mendidik dan kontra produktif.

5. Manajemen Pembiayaan Pendidikan Berbasis Pendidikan Karakter

Pengelolaan biaya pendidikan di sekolah dapat memberikan kontribusi yang sangat signifikan dalam pendidikan karakter di sekolah. Kepala sekolah harus dapat mengalokasikan sebagian biaya pendidikan untuk memfasilitasi pendidikan karakter, seperti untuk membangun tempat ibadah, menyelenggarakan program pelatihan Emotional Spiritual Quotion (ESQ), menyelenggarakan workshop penyusunan silabus dan RPP berbasis pendidikan karakter. Pengalokasian biaya untuk program dan kegiatan pendidikan karakter ini dituangkan pada Rencana Kerja Sekolah (RKS) dan Rencana Kegiatan dan Anggaran Sekolah (RKAS).

Di samping dari sisi alokasi dana untuk kegiatan pendidikan karakter, kepala sekolah harus dapat menunjukkan bahwa biaya pendidikan di sekolah pun dikelola dengan menunjukkan karakter yang positif. Sebagai contoh, sekolah mengelola keuangan dengan jujur, memberikan keringanan dan bahkan menggratiskan dari segala iuran sekolah bagi orang tua siswa yang tidak mampu, ada laporan berkala dan transparan kepada stakeholder, mempersilahkan auditor mengaudit secara berkala.

Pengelolaan berbasis pada IT sangat membantu kepala sekolah atau atau pengelola keuangan untuk merencanakan, menggunakan, memonitor, maupun membuat laporan pertanggung jawaban keuangan dengan lebih transparan dan akuntabel.

\section{F. Penutup}

Berdasarkan uraian-uraian yang telah disebutkan di atas jelas bahwa setiap manajemen komponen pendidikan dapat mengandung dan digunakan untuk memfasilitasi nilai-nilai karakter yang akan diinternalisasikan kepada warga sekolah (kepala sekolah, para guru, tenaga administrasi dan peserta didik). Penanaman nilainilai karakter tersebut dilaksanakan secara terpadu, baik dalam pembelajaran, kegiatan ekstra kurikuler siswa maupun pengelolaan sekolah secara keseluruhan. Keterlaksanaan pendidikan karakter itu diperlukan adanya dukungan sarana dan prasarana, tenaga, serta biaya pendidikan dan dioptimalkan dengan pembiasaan kegiatan di sekolah. Guru dan kepala sekolah dalam setiap tingkah lakunya menjadi panutan para peserta didik. Oleh karena itu, filosofi Ing Ngarso sung Tulodho, Ing Madyo Mangun Karso, Tut Wuri Handayani, harus menjadi panutan. 


\section{Daftar Rujukan}

Borgman, Dean. Character Overview. http://www.centerforyouth.org/files/PDF/ Ofiles/Overviews/Character\%20overview.pdf

Direktorat Pembinaan SMP, Kemdiknas. (2011a). Informasi Program Pembinaan Sekolah Menengah Pertama. Jakarta: Direktorat Pembinaan SMP.

Direktorat Pembinaan SMP, Kemdiknas. (2011b). Pendidikan Karakter di Sekolah Menengah Pertama. Jakarta: Direktorat Pembinaan SMP.

Lickona, T. 2015. Educating for Character: How Our Schools Can Teach Respect and Responsibility. Jakarta: Bumi Aksara.

Menteri Pendidikan Nasional RI, 2006c. Peraturan Menteri Pendidikan Nasional Republik Indonesia Nomor 24 Tahun 2006 tentang Pelaksanaan Peraturan Menteri Pendidikan Nasional Republik Indonesia Nomor 22 dan 23 Tahun 2006

Menteri Pendidikan Nasional RI, 2007a. Peraturan Menteri Pendidikan Nasional Republik Indonesia Nomor 19 Tahun 2007 tentang Standar Pengelolaan Pendidikan

Mulyasa, H.E., 2013. Manajemen Pendidikan Karakter. Jakarta; Bumi Aksara.

Pusat Kurikulum, Balitbang Kemdiknas, 2010. Bahan Pelatihan Penguatan metodologi Pembelajaran Berdasarkan Nilai-Nilai Budaya untuk Membentuk Daya Saing dan Karakter Bangsa. Jakarta: Kemdiknas.

Republik Indonesia, 2005a. Peraturan Pemerintah Nomor 19 Tahun 2005 tentang Standar Nasional Pendidikan

Republik Indonesia, 2005b. Undang-Undang Nomor 14 Tahun 2005 tentang Guru dan Dosen

Solihu, A.K.H. 2011. The Islamic Worldview, Ethics and Civilization: Issues in Contemporary Interdisciplinary Discourse. Malaysia: International Islamic University Malaysia.

Vessels, G., \& Huitt, W. (2005). Moral and character development. Paper presented at the National Youth at Risk Conference, Savannah, GA, March 8-10. http://www. edpsycinteractive.org/papers/chardev.pdf

Zuriah, N., 2008. Pendidikan Moral dan Budi Pekerti dalam Perspektif Perubahan. Jakarta: Bumi Aksara. 